\title{
Kvinder og khat i Yemen
}

Khattygning har længe været naturligt for de fleste yemenitiske mænd. Den omfatter nu i stigende grad også kvinderne. Dette vækker ikke bare blandede følelser hos den ældre generation, men ligeledes hos landets sundhedssektor. På flere områder kan man allerede se den negative effekt af kvindernes stigende khatforbrug.

Saliha Marie Fettah er ansat som videnskabelig assistent på Center for Mellemøststudier, Syddansk Universitet, og er tilknyttet et samarbejde mellem Center for Mellemøststudier i Odense og Gender Development Research \& Studies Centre på Sanaa Universitet i Yemen. 
TEKST: Saliha Marie Fetteh

VERDENSBANKEN VURDERER i en rapport fra 2007, at omkring 33 prosent af kvinderne i Yemen regelmæssigt tygger khat og at khat forbruget både hos mænd og kvinder er størst i de egne af landet, hvor der produceres khat. I hovedstaden Sanaa tygger således cirka 53 prosent af kvinderne khat og i Taiz, hvor kvinder som det eneste sted i Yemen også sælger khat, er gennemsnittet helt oppe på 55 prosent. Værst står det overraskende til i gruppen af højtuddannede kvinder, hvor hele 56 prosent jævnligt tygger khat. ${ }^{\mathrm{T}}$

Men hvad er grunden til det stigende forbrug af khat hos kvinderne og hvordan påvirker det dem?

\section{Hvad er khat?}

Khat, eller catha edulis, er en naturlig form for narkotikum fra celastrus edulis- planten, som blandt andet indeholder cathin, ascorbinsyre, sukker og vitamin C foruden efedrin, der ifølge WHO (The World Health Organization) hører under kategorien amfetamin.

De friske khatbladene tygges let af forbrugeren og lagres derefter i mundhulen, hvor de blandes med ens naturlige mundvand. Med korte mellemrum suges saften ud af bladene, nye blade stoppes i munden og processen gentages, hvorved en euforiserende virkning opnås. Små lysegrønne blade er de bedste, da de ikke er bitre, giver brugeren en følelse af kayf (velvære), og ikke forårsager bivirkninger dagen efter.

Khatbladenes effekt kan variere fra person til person, men giver ofte brugeren en følelse af frihed, appetitløshed, hyperaktivitet samt en næsten ustyrlig lyst til at tale. Et jævnligt forbrug af khat kan medføre bivirkninger som forhøjet blodtryk, depressioner, søvnløshed eller dyb søvn, diarre, impotens, dårlige tænder og i sjældne tilfælde aggressivitet foruden at risikoen for et hjertetilfælde hos forbrugere af khat er 49 prosent højere end normalt.

Der opstår ikke fysiske abstinenser, hvis man stopper med at tygge khat og de ovenfor nævnte symptomer forsvinder når forbruget ophører, hvilket har skabt uenighed blandt fagfolk om, hvorvidt man kan betegne khat som afhængighedsdannende. Imidlertid er der enighed om, at forbrugeren kan udvikle en slags psykosocial afhængighed.

Det har heller ikke entydigt kunne bevises videnskabeligt, at khat ved et moderat forbrug skader brugeres helbred. De seneste års farmakologiske og medicinske undersøgelser af khatplantens effekt, foretaget af både yemenitiske og amerikanske forskere, har kun fastslået at planten inde- 
holder en slags naturlig amfetamin kaldet cathinon, som blant andet kan påvirke centralnervesystemet og at den eneste forskel mellem khat og amfetamin er varigheden af effekten. ${ }^{2}$

Undersøgelser foretaget af Det Yemenitiske Sundhedsministerium i samarbejde med Sanaa Universitet i 2006 har desuden vist, at det stigende forbrug af khat er årsag til flere tilfælde af kræft i mundhulen, hvilket begrundes med et stort forbrug af ulovligt importerede pesticider i khatplantagerne. ${ }^{3}$

\section{Hvorfor tygger kvinder khat?}

Der er, foruden den kendsgerning at khat er et meget populært stof og at forbruget af narkotikummet er dybt integreret i hele den yemenitiske kultur og livsstil, flere årsager til det stigende forbrug hos kvinderne.

Khat var frem til I970erne et luksusprodukt, hovedsagligt forbeholdt den velhavende del af befolkningen, der havde både tid og råd til om eftermiddagen at mødes med venner, kollegaer eller familiemedlemmer for at tygge khat, sludre og ryge den traditionelle yemenitiske vandpibe al-mada'a. Efterhånden bredte skikken sig til også at omfatte de lidt ældre gifte kvinder, som ligeledes havde tid og råd til khat. Til gengæld har det indtil for få år siden været socialt uacceptabelt for anstændige ugifte piger at tygge de saftige, bitre og elysæiske blade, hvorfor khattygning hos unge kvinder kun fandt sted hos nogle ganske få velhavende familier i de større byer.

I dag har mange unge kvinder i byerne brudt dette mønster og det er blevet populært at afholde khatsessioner om eftermiddagen, hvor kvinderne i hinandens sel- skab tygger khat, lytter til musik, diskuterer mode og sex, mens de ryger cigaretter eller æbletobak fra små kulørte importerede vandpiber.

Mange traditionelle familier er chokerede over, at deres døtre åbenlyst både tygger khat og ryger. Og at det især er hos den veluddannede gruppe af befolkningen, at kvindernes forbrug er stigende chokerer yderligere, da den brede befolkning har en forventning om, at den veluddannede klasse af samfundet burde være et positivt forbillede for alle andre. ${ }^{4}$

Men ifølge flere yemenitiske undersøgelser spiller uddannelsesniveauet ingen rolle for, hvorvidt kvinder tygger khat eller ej. Derimod er kvinder opvokset i hjem, hvor forældrene jævnligt tyggede khat, i højere grad selv tilbøjelige til som voksne at tygge khat, da de anser khat for at være en naturlig del af deres egen hverdag og af hele den yemenitiske kultur som sådan. Både yemenitiske de undersøgelser og studierne fra Verdensbanken har desuden vist at khatforbruget hos kvinder i byerne er meget højere end hos kvinder på landet, hvilket begrundes med at kvinder på landet for det første arbejder fra tidlig morgen til sent aften og derfor ikke har tid til overs til at sidde og tygge. Desuden anses det især på landet for umoralsk, at kvinder tygger khat. Kvinderne i byerne lever en isoleret tilværelse $\mathrm{i}$ hjemmene og har tid til rådighed om eftermiddagen. Og da det ikke er normen med fritidstilbud for kvinder i Yemen udenfor hjemmene, samles kvinderne på skift i hjemmene og tygger khat på lige fod med mændene. Sidst men ikke mindst så starter mange kvinder først med at tygge khat efter de er blevet gift, da mange mænd ligefrem presser deres hustruer til at tygge khat sammen med dem 
om eftermiddagen. Således udtaler en chauffør $i$ et interview i Yemen Times den I4. januar 2006 at: "Jeg køber altid khat til min hustru og opmuntrer hende til også at tygge. Og især hvis hun tygger khat sammen med mig." ${ }^{\prime 5}$ For khattygning, der ellers foregår i kønsopdelte grupper, betragtes ligeledes som noget intimt og hyggeligt mellem ægtepar og de mange yemenitter er af den opfattelse, at khat har en positiv effekt på deres sexliv. ${ }^{6}$

Khatsessionerne har i dag erstattet næsten alle andre former for socialisering og afslapning i Yemen. Khat har udviklet sig fra at være et stimulerende middel til et kulturelt fænomen, der som en naturlig del af hverdagen nu ses hos både mænd og kvinder i alle samfundsklasser. Khattygningen er først og fremmest en social aktivitet, hvorfor man kan risikere at ryge udenfor fællesskabet, hvis man ikke tygger. Foruden presset fra ægtemændenes side af, finder der desuden en slags socialt gruppepres sted indbyrdes mellem kvinderne. Kvinder, der ikke tygger, anses i mange miljø for ikke bare at være outsidere "Rigtige yemenitter tygger da khat"- men beskyldes ironisk nok også af andre kvinder for at være gammeldags. Det er ved khatsessionerne om eftermiddagen, at man mødes og indgår nye bekendtskaber. Der er for både mænd og kvinder en vis social prestige forbundet med at deltage $\mathrm{i}$ khatsessionerne, hvor alle medbringer deres egen ration og hvor det gælder for khat som med vin i den vestlige del af verdenen, at man gerne vil kunne dele $u d$ af eller lade sig se med den fineste khatkvalitet, der genkendes på khatbladenes farve og størrelse. ${ }^{7}$

Overgangen fra det traditionelle til det moderne har de senere år bevirket at flere unge kvinder er kommet ud på arbejdsmarkedet, hvilket ikke bare har betydet en ændring af deres isolerede hverdag, men også at de nu har deres egen indkomst. En del af disse udearbejdende kvinder danner på lige fod med deres mandlige kollegaer netværker, hvor de mødes med andre kvinder for at tygge khat om ikke hver dag så torsdag og fredag, hvor de holder weekend. Denne tendens er dog ikke i sig selv noget nyt, da mange gifte kvinder i Yemen altid har arbejdet $\mathrm{i}$ hjemmene med for eksempel syning, fremstilling af røgelse og så videre, hvorved de har tjent til dagens rations af

\section{Ifølge yemenitiske undersøgelser spiller uddannelsesniveauet ingen rolle for hvorvidt kvinder tygger khat eller ej.}

khat, som de så enten tyggede alene, sammen med ægtemanden eller med en veninde. Det nye er, foruden den kendsgerning at khattygning nærmest blevet en slags tegn på modernitet og frigjorthed, hele den sociale iscenesættelse hos den unge generation med khat som centrum, som kan i nogle tilfælde koster kvinderne hele deres månedsløn. Khattygning er blevet et socialt fællesskab, som kompenserer for at der i det konservative Yemen ikke findes mange alternativer for kvinder, hvorfor de unge kvinder bruger dette sociale fællesskab, som udstillingsvindue med khattygning som centrum, hvor de møder op og fremviser modetøj, make-up, parfume og smykker, som de har på til khatsessionerne.

Mange af disse unge kvinder ignorerer, at deres daglige forbrug af khat ikke bare 
har en økonomisk slagside, men også har både sociale, fysiske og psykiske konsekvenser ikke bare for dem selv, men også for deres familier og det yemenitiske samfund som sådan. ${ }^{8}$

\section{Khat, økonomi og sundhed}

Prisen på et bundt khat - nok til en persons eftermiddagsforbrug - varierer meget, men ligger fra 500 riyal (cirka 20 danske kroner) og helt op til 50000 riyal (2000 danske kroner) eller mere. Hvad enten man køber den billige eller dyre slags khat så er det daglige forbrug en anselig økonomisk belastning for enhver yemenitisk familie, men især for den fattige. Omkring 40 prosent af den yemenitiske befolkning lever for under 7000 kroner om året, hvilket betyder at et khatforbrug hos et ægtepar med en månedsindkomst på I5 o०० riyal (cirka 540 danske kroner) er en økonomisk katastrofe. Khat anses derfor ifølge Verdensbanken for at være er en af hovedårsagerne til den store fattigdom i Yemen og man regner med at omkring I/4 af en families indkomst bruges på khat. ${ }^{9}$

Det har længe været en kendsgerning, at mange yemenitter springer aftensmaden over efter en eftermiddag med khattygning, da en af plantens bivirkninger som tidligere nævnt er appetitløshed. Dette har blandt andet bevirket at befolkningens proteinindtag er alt for lille, hvilket er et problem i Yemen, hvor der allerede er store problemer med fejlernæring og underernæring både hos børn og voksne, der på grund af fattigdom og uvidenhed ikke får den næring, som de har behov for.

Kvindernes daglige khatforbrug har endnu en sundhedsmæssig ulempe, idet mange kvinder ignorerer de risici, der er forbundet med khattygning under gra- viditet. Undersøgelser har vist, at et dagligt forbrug af khat i lighed med rygning hos gravide kvinder er hovedårsagen til at de ofte føder undervægtige børn. Khat reducerer desuden ikke bare mængden af modermælk, men påvirker også mælkens kvalitet og smag, hvorfor mange nyfødte børn ikke vil ammes. Dette fører ikke blot til yderligere underernæring af mange spædbørn, men påvirker også familiens økonomi, da kvinden i stedet må købe modermælkserstatning til barnet. I øvrigt har kvinder tidligere begrundet khattygning under deres graviditet med, at de ikke bare selv undgik at tage så meget på i vægt under graviditeten, men også at de havde nemmere ved at føde, når barnet ikke var så stort.

I slutningen af 2007 gennemførte den yemenitiske NGO Yemen organisation for Women and Child Development (SOUL), der arbejder for en forbedring af yemenitiske kvinder og børns vilkår i samarbejde med Qatar Charity, en kampagne i Sanaa for at informere gravide kvinder omkring risikoen ved at tygge khat og ryge under graviditet. Ud over distribueringen af plakater, der blev hængt op rundt omkring på skoler, gymnasier, hos læger, tandlæger og på apotekerne, blev der også sendt SMSbeskeder ud til mere end Ioo ooo personer med et telefonabonnement hos Yemen Net, det nationale telefonselskab, foruden at der blev informeret $i$ både TV og radio. Sidst men ikke mindst blev der afholdt forskellige aktiviteter på fire store pigeskoler i Sanaa, med henblik på at informere den næste generation af mødre om, hvad et eventuelt khatmisbrug kan komme til at betyde ikke bare for deres eget liv, men også for deres børns. ${ }^{\text {I० }}$

Et andet problem er ifølge Dr. Abdul- 


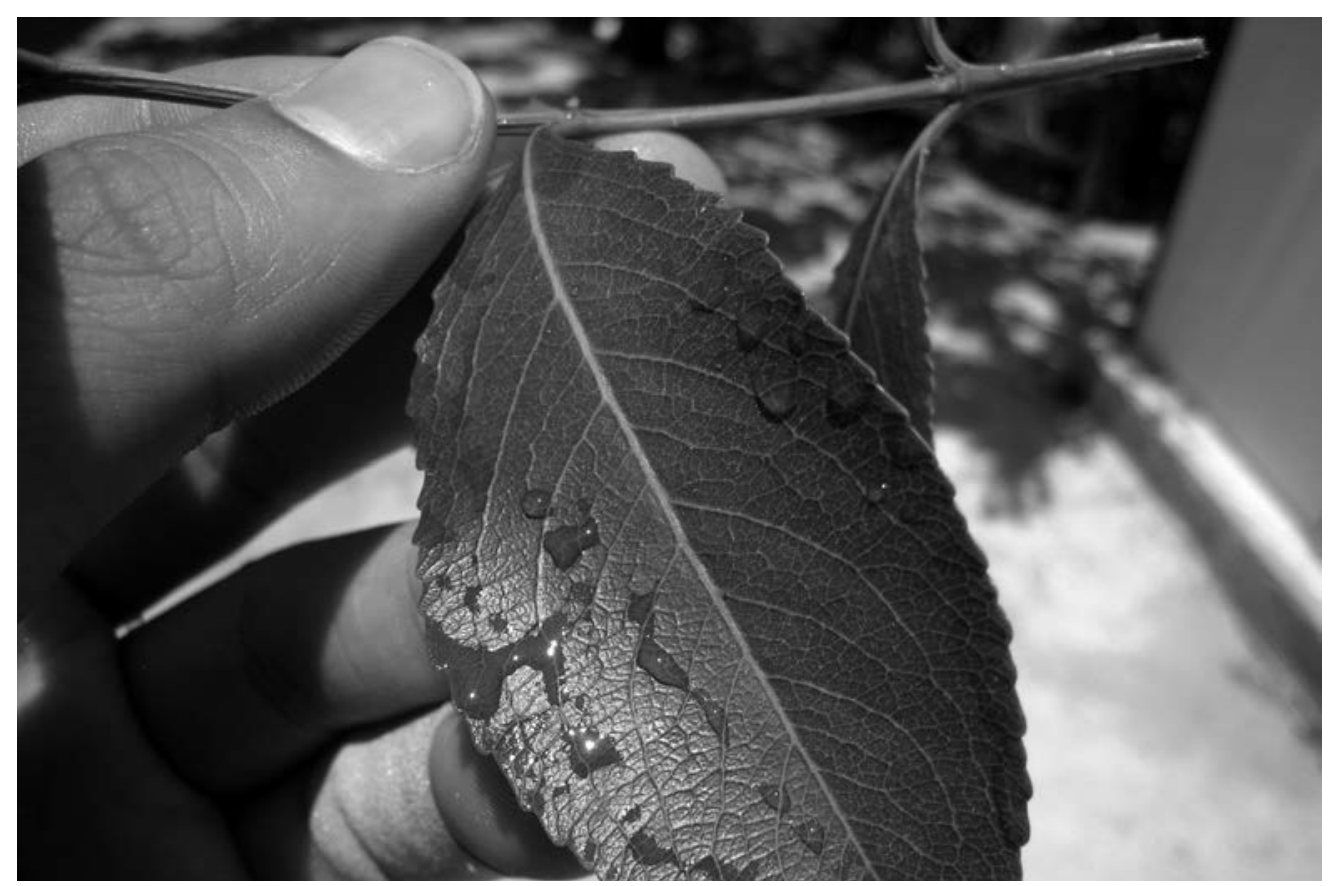

De mange pesticider der anvendes i mange khatplantager om vinteren er endnu et problem.

Rahman Thabet, miljøforsker ved Sanaa Universitet, de mange pesticider der anvendes i mange khatplantager om vinteren. Pesticiderne har en enorm effekt på folks helbred og igen især på gravide kvinder og deres fostre, som bliver lettere forgiftede, hver gang moderen tygger sprøjtet khat og khatsaften cirkulerer i hendes krop og efter fødslen via modermælken, hvilket på sigt kan medføre alvorlige helbredsproblemer for barnet. ${ }^{\text {II }}$

Imidlertid tager nogle kvinder sig tilsyneladende ikke af kampagnernes budskab. Fatima Mohammed er 32 år gammel, folkeskolelærer, og gravid i fjerde måned med det fjerde barn. Hun tygger trods sin graviditet khat hver eftermiddag i cirka fire timer sammen med veninderne, dog uden at ryge vandpibe. Da jeg spurgte hende om det ikke kunne skade fostret svarede hun mig frejdigt at: "Det har ikke skadet de tre første børn, så hvorfor skulle det skade nummer fire?", hvorefter hun frejdigt tyggede videre. Fatima er bare ét eksempel på gravide kvinder der tygger khat, men hun repræsenterer efter min erfaring, via fire års feltarbejde i Yemen, mange kvinders indstilling til khattygning under graviditet.

\section{Løsning?}

Hidtil har ingen kunne finde en løsning på det overdrevne khatforbrug hos yemenitiske mænd så spørgsmålet er, hvorvidt der kan findes en løsning på kvindernes stigende forbrug. Under alle omstændigheder er det ikke realistisk at tro på, at man i løbet af nogle år kan udrydde en skik, som har været en naturlig del af den yemenitiske kultur i mere end 700 år. Alle tiltag, både de private og dem fra regeringens side, for at begrænse produktion og forbrug af khat, har da heller ikke haft den store effekt. 
Det er den yemenitiske regeringens opgave, i samarbejde med både undervisnings- sundheds- og landbrugssektoren, de religiøse ledere og medierne, at føre en målrettet kampagne mod khat og forbrugets konsekvenser, både for det yemenitiske samfund og den enkelte bruger, samtidig med at der tilbydes alternative aktiviteter og jobmuligheder. Et godt sted at starte er altid folkeskolerne, hvor det i Yemen er muligt at føre kampagner på linje med kampagnerne i Europa og USA mod tobaksrygning, men med en bevidsthed omkring at holdningsændringer tager tid, ofte en generation eller to, hvilket ikke er

\section{"Det har ikke skadet de tre første børn, så hvorfor skulle det skade nummer fire?"}

ensbetydende med at man skal opgive og lade stå til. Desværre ville en landsdækkende kampagne i Yemen, på nuværende tidspunkt, nok ikke finde megen støtte, hverken politisk eller hos den brede befolkning, andet end hos et mindretal. Der er for mange kræfter i samfundet, som har store økonomiske fordele af khatproduktionen og der er desværre i dag nok ikke nogen yemenit, hvis liv ikke på den ene eller anden måde er påvirket af khat.

Det findes i dag en gruppe af samfundet, som helt har droppet forbruget af khat. Denne gruppe består hovedsagligt af islamister påvirket af det wahabistiske Saudi-Arabien, hvor både salg og forbrug af khat er strengt forbudt. Disse grupper udgiver både foldere og små bøger omkring forbruget af khat og hvilken negativ indflydelse dette har på hele det yemenitiske samfund. Gruppen begrunder deres modstand ud fra et religiøst synspunkt, hvilket i Yemen plejer at kunne påvirke majoriteten af befolkningen. Bare ikke når det drejer sig om khat. ${ }^{12}$

Ved en rundspørgsel foretaget af Yemen Times i 2005 blandt 769 personer i Sanaa fortalte omkring 78 prosent af de adspurgte, at de kun tyggede khat fordi der simpelthen ikke var andet at foretage sig om eftermiddagen. ${ }^{13}$ Dette gør sig igen især gældende for de unge piger og kvindernes vedkommende, der som tidligere nævnt, ofte lever en isoleret tilværelse i hjemmene, da det ikke er velset i Yemen, at kvinder forlader hjemmet uden familien eller ægtemanden for at deltage i offentlige arrangementer. De yemenitiske aviser gør jævnligt opmærksomme på problemet og opfordrer til åbne svømmehaller, sportsklubber, flere internetcafeer og så videre kun for kvinder, hvilket kan være med at skabe andre muligheder for adspredelse hos kvinderne end at sidde hver eftermiddag og tygge khat, ryge og snakke.

I marts 2002 blev der i Sanaa afholdt den første nationale konference om khatplantens negative indvirkning på det yemenitiske samfund og landets økonomi. Men på trods af, at konferencen udmundede i nogle retningslinjer for en oplysningskampagne mod khat, så ser det ikke ud til at kampagnen eller det såkaldte Nationale Forbund for Bekæmpelse af Khat har haft nogen effekt på hverken khatproduktionen eller forbruget, som fortsat er stigende. Årsagerne hertil er mange, men en af dem er uden tvivl at khatsektoren har skabt arbejdspladser til mange mennesker - noget som regeringen ikke har formået - 
og at mange tusinder familier er afhængige af at dyrke, transportere eller sælge khat. Og uden at kunne tilbyde noget til gengæld er regeringen ikke $i$ stand til at gribe ind med drastiske tiltag som for eksempel et forbud mod dyrkningen og brugen af khat. Regeringens manglende initiativ har medført, at en stor del af befolkningens opfattelse af elitens erklæringer om en begrænsning af khatdyrkningen er, at de er rettet mod det internationale samfund og ikke fordi regeringen, eller præsident Saleh, ønsker at komme dyrkningen og forbruget til livs. Efter sigende er det netop præsident Salehs familie, foruden nogle af de mest indflydelsesrige familier og stammer i Yemen, der er kendte for at dyrke den fineste og dyreste khat, hvorfor de temmelig sikkert ikke har den store interesse i at komme khatdyrkningen til livs. ${ }^{\mathrm{I}}$

Alt i alt kan det konkluderes, at der foruden det sociale aspekt og gruppepresset er flere årsager til det stigende khatforbrug hos kvinderne. Yemen har i løbet af de sidste 20 år gennemgået en modernisering, der blandt andet har medført at især kvinderne i storbyerne føler sig presset fra flere sider af. Højere og mere uddannelse har givet flere kvinder mulighed for at komme ud på arbejdsmarkedet, hvilket sideløbende har forøget presset på dem i hjemmene, hvor de stadigvæk forventes at leve op til det traditionelle kvindeideal. En anden og større gruppe af kvinder lever en beskyttet og isoleret tilværelse i hjemmene, hvor deres eneste fornøjelse er khatsessionerne sammen med andre kvinder. Kendetegnende for begge grupper er, at de har fået mere tid til rådighed på grund af moderne bekvemligheder. Sidst men ikke mindst så har den kendgerning, at flere kvinder i dag tjener deres egne penge gjort dem til stor- forbrugere af khat fordi de har både tid og råd til det. Det kan derfor konkluderes, at modernitetens bekvemmeligheder og en forbedring af mange kvinders økonomiske vilkår bidrager til at bevare en kulturel praksis, som i bund og grund ikke bare er skadelig for kvinderne selv, men også for hele samfundsudviklingen i Yemen som sådan.

\section{$\cdot f \cdot$}

I World Bank Report No. 39738-YE: "Yemen Towards Qat demand Reduction - Juni 2007.

2 Khat (Catha edulis) - www.alb2c3.com/drugs/khatr.htm

3 Rouis Mustapha: "Yemen towards qat demand reduction" i Yemen Observer, 25. September 2007.

4 Al-Anesi Arwa: "The Spread of Qat among Women" i Yemen Times, I4. januar 2006.

5 Al-Anesi Arwa: "The Spread of Qat among Women" i Yemen Times, I4. januar 2006.

6 Thabet Hamed: "Qat increase sexdrive but inhibits sexual performances" i Yemen Times, II. februar 2008.

7 Egne erfaringer fra feltarbejde udført i Yemen blandt kvinder i Sanaa.

8 Mujalli Wojoud: "Where do Yemeni girls go for entertainment?" i Yemen Times, 3I. december 2007.

9 Ward Christopher: "Yemen: CDR Building Block - Qat" www.worldbank.org/yemen

Io Yemen: Efforts to reduce rising number of female qat chewers - www.irinnews.org/yemen. IRIN - UN Office for the Coordination of Humanitarian Affairs.

II Ghaleb Thuria: "New Campaign calls for Pregnant and Breastfeeding Mothers to quit Qat" i Yemen Observer, 20. november 2007.

I2 Samtale med Rashida Hamdani - formand for Women National Committee og khatplantageejer sommeren 2007.

I3 Al-Masmari Hakim: "The positive aspect of Qat" i Yemen Times, I7. november 2005 .

I4 Bøgesvang Malene: "Qat - Yemens onde plante?" Mellemøstinformation årgang 2005, nr. 6 . 